\title{
Tourism and sustainability indicators as planning tools for a coastal NPA in Mexico
}

\author{
E. Núñez-Lara, A. Cahuich-Carrillo, A. Delgado-Estrella \\ \& S. Laffon-Leal \\ Universidad Autónoma del Carmen, Mexico
}

\begin{abstract}
The southern coast of Campeche State, in the Gulf of Mexico, is currently transitioning from traditional activities to tourism. This activity might represent a sustainable alternative for the use of the highly diverse natural and cultural resources and a socioeconomic benefit for the people of the region. The objective of the study was to conduct a multidisciplinary study to analyse the socioeconomic and environmental context of a coastal region located within a Natural Protected Area. The approach was primarily based on tourism and sustainability indicators selected in order to understand: i) the historic use of natural resources; ii) the perception of residents and visitors regarding the current transition to tourism; and iii) whether stakeholders' prospective analysis is based on accurate information and on a sustainable model. Results revealed that the historic exploitation of natural resources has been intensive and clearly unsustainable. Nowadays, estuarine ecosystems seem to be relatively well conserved, enclosing populations of dolphins, sea turtles and sea birds. Socioeconomic indicators show that poverty and marginalization result in a low quality of life, inaccessible basic services and moderate development opportunities. Tourism indicators showed that both local residents and visitors perceive eco-tourism as a good opportunity for socioeconomic progress, although they only distantly recognize a threat to natural resources. The results of this study offer a simplified summary based on accurate indicators and a sustainable perspective, pretending contribute in the planning process of the region.
\end{abstract}

Keywords: sustainable development, ecotourism, sustainability indicators, tourism indicators. 


\section{Introduction}

Currently, tourism is a fundamental sector in the global economy, particularly for the international trade in public services. An informed planning process is essential to ensuring that tourism contributes sustainably to the regional economy, preserving environmental and cultural conditions while simultaneously attending to the needs of the visitors [1]. It provides opportunities for visitors to experience nature and culture and to learn about the importance of biodiversity conservation. Since the United Nations Conference on Environment and Development, NGOs, government administrators, the academic community and tourism managers have been working to gather appropriate information for designing sustainability and tourism indicators. Since that time, many countries have designed sets of sustainability and tourism indicators, elaborated according to regional particularities and their development goals [2]. Indicators are essential tools for the informed participation of local communities, government agencies and decision makers and are also the methodological base for monitoring and implementing sustainable practices.

Alternative tourism emerges as a counterpoint to conventional massive tourism, and focuses on the promotion of places with vast natural capital, travelling to little-known places and trying to stimulate sensations, knowledge and understanding more than commodity and recreation [3]. The ecotourism concept arises as the result of the integration of sustainable development and tourism and focuses on trying to find and nurture alternatives for more environmentally friendly travelling [4]. The principles of sustainable tourism include: i) using natural resources optimally, affecting nature as little as possible; ii) promoting respect for the social and cultural traditions of local communities and preserving their cultural heritage; and iii) encouraging intercultural tolerance and education in the broadest sense [5].

Along with Brazil, Indonesia, Australia and Colombia, Mexico is on the list of the five mega-diverse countries (UINC, 2005) due to the archaeological and cultural richness present in the southern region of the country. Due to these idiosyncrasies, Mexico is considered an ideal country for ecotourism. However, the tourist destinations in Mexico manifest problems of land use, lack of informed planning, pollution, poor water quality, unregulated activities, threats to biodiversity, absence of monitoring and other glitches that complicate progress toward sustainable tourism. Previous studies have demonstrated that sustainability in NPAs can be advanced through the development of nature tourism, preservation of the natural environment and the socioeconomic development of the local people [6-8].

The main objective of the study was to analyse the socioeconomic indicators of the human communities in an NPA of the coastal region of the Gulf of Mexico by using sustainability and tourism indicators to identify past, present and potential ecotourism uses of natural resources. We believe that providing an overall analysis based on a scientific methodology can contribute to developing an integrated resource planning process. 


\section{Methods}

\subsection{Study area}

The "Laguna de Términos" NPA estuarine system is located in Campeche State, in the western part of the Yucatan Peninsula in Mexico. Approximately ten small villages (pop. $<5,000)$ and one major city (pop. $>200,000)$ exist within the reserve area, fig. 1. The traditional production activities in the region are artisan fishing, agriculture and regional trade. Different natural resources have been exploited in this region for the past 200 years. Development of tourist activities began about ten years ago as an initiative of village residents, who use traditional knowledge of the natural resources to offer guided visits to pristine places. Since then, the tourism infrastructure and services have increased progressively, but this increase has unfortunately come without a proper, informed management planning process.

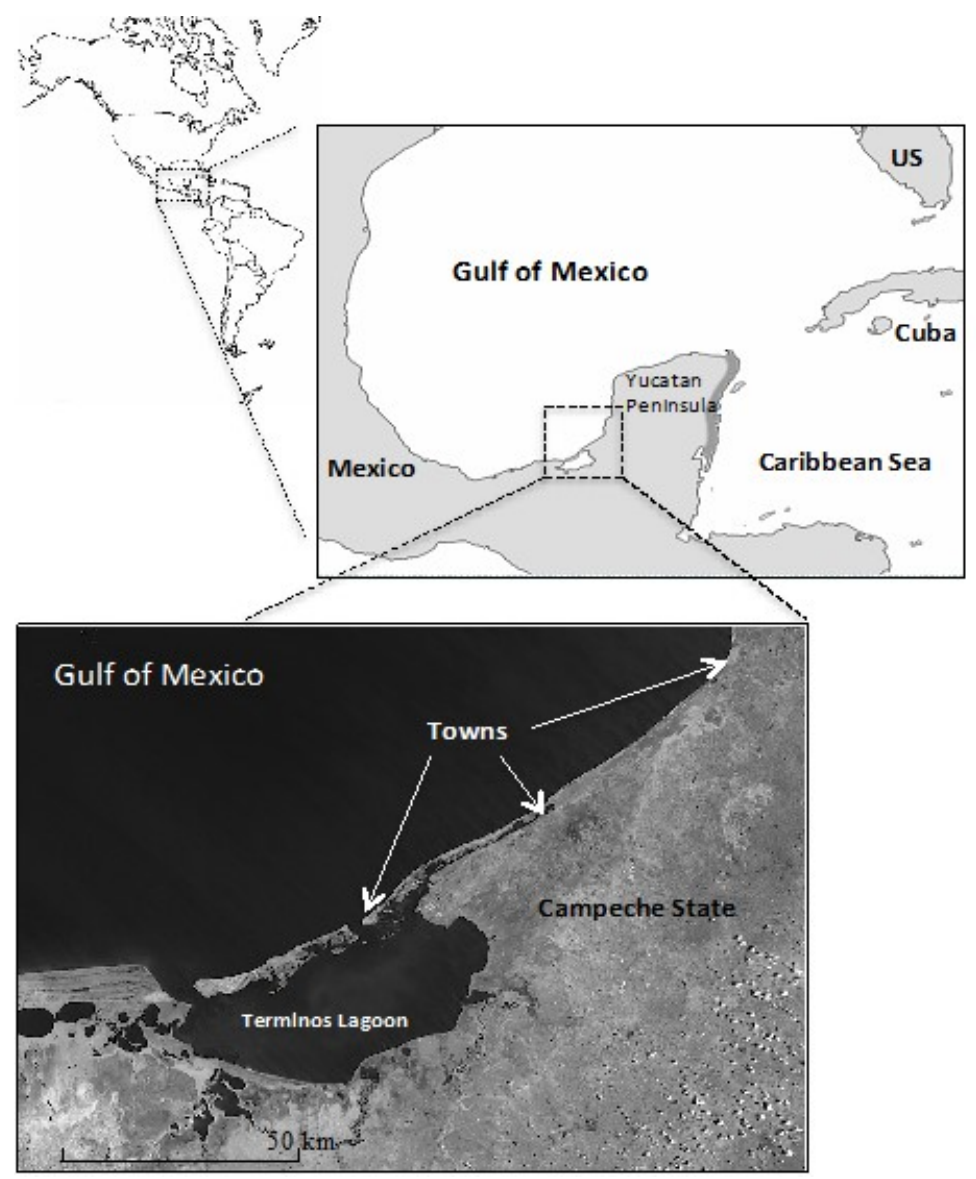

Figure 1: Natural protected and study area. 


\subsection{Procedure}

To identify the best set of indicators and the information needed to attain an integral analysis of the region's sustainability and tourism issues, we roughly followed the step-by-step procedure described in the WTO Guidebook [1] in the context of the tourism planning process, with some variations according to the particularities of the study sites and the available information, table 1 .

Table 1: Steps followed for the identification of tourism and sustainability indicators and integration analysis.

\begin{tabular}{|c|c|}
\hline Step & Description \\
\hline 1. Preliminary planning & $\begin{array}{l}\text { Multidisciplinary working group } \\
\text { meetings and prospective surveys at the } \\
\text { region }\end{array}$ \\
\hline $\begin{array}{l}\text { 2. Delimitation and general } \\
\text { description of the interest sites }\end{array}$ & $\begin{array}{l}\text { Historic and existing information } \\
\text { searching (geographic, demographic, } \\
\text { economic, social, natural and cultural) }\end{array}$ \\
\hline $\begin{array}{l}\text { 3. Identification and design of the } \\
\text { primacy set of indicators }\end{array}$ & $\begin{array}{l}\text { Indicators selection process by the } \\
\text { multidisciplinary group according to } \\
\text { published papers guidelines and } \\
\text { methodologies }\end{array}$ \\
\hline $\begin{array}{l}\text { 4. Establishment of participatory } \\
\text { process and data acquisition }\end{array}$ & $\begin{array}{l}\text { In site surveys to residents and visitors } \\
\text { (interviews, questionnaires, } \\
\text { government statistics), environmental } \\
\text { sampling }\end{array}$ \\
\hline $\begin{array}{l}\text { 5. Integrative analysis } \\
\text { discussion }\end{array}$ & $\begin{array}{l}\text { Numerical exploration of variables and } \\
\text { indicators. Qualitative/quantitative } \\
\text { overall analysis }\end{array}$ \\
\hline 6. Results communication & $\begin{array}{l}\text { Diffusion of results and prospective } \\
\text { proposals to stakeholders through } \\
\text { synthetic documents, seminars, } \\
\text { conferences and } \\
\text { publications. }\end{array}$ \\
\hline
\end{tabular}

The working group was composed of academics from various research disciplines, government administrators, local community members and students. We searched for documented information about the past productive activities of the region and general living conditions. That information was complemented by current demographic, social, economic and environmental statistics obtained from government publications. The working group used the gathered information to choose a list of primary sustainability themes and indicators concerning the identified problems and established objectives. Particular attention was paid to indicators recognised by other authors for their relevance to addressing regionalscale issues associated with planning and management. 
Surveys were focused on two of the villages where ecotourism activities are promoted: Isla Aguada and Sabancuy. Previously designed questionnaires and interviews were given to 500 residents and 231 visitors. Both groups were considered important for a comprehensive diagnosis because the first group has a better sense of the appropriation of natural and cultural resources, while the second group reflects the requirements of tourist services and infrastructure. The resident sample size was calculated from the total adult population of the two villages $(>18$ years) at $95 \%$ probability, while the visitor sample size was estimated using the average population registered in the tourist book of the Isla Aguada dock office in a spring-summer season.

The environmental sampling was conducted at the main ecosystems adjacent to the two villages. Sampling sites where distributed uniformly around the towns, covering the main habitats and zones with marked human influence. Surveys included water quality and physicochemical parameters (e.g., BOD, faecal coliforms, $\mathrm{pH}$, etc.) as well as ecological data about the focal biological populations (dolphins, sea turtles and birds). Basic statistics were computed to obtain indicators from raw data. The resulting values were standardised to a percentage scale to allow for an integral and comparative interpretation. Semiquantitative information from questionnaires was used to generate summary contingency tables. The comparative graphics were complemented with qualitative information to extend the interpretation and capture the complexity of the system. We also draw preliminary touristic proposals based on a sustainable use of natural resources and bearing in mind the priorities of both local societies and external stakeholders.

\section{Results}

To gain a comprehensive understanding of the evolution of the region in terms of the natural resource use and the changes in productive activities toward tourism interests, we described three different moments: the historic context from before the study period, described using available, published information; the present condition of the sites (2010-2012), described by tourism and sustainability indicators; and prospective ecotourism scenarios for the region and the NPA.

\subsection{Historic context of the study region}

From the eighteenth century to the beginning of the twentieth century, Isla Aguada was an island visited only by fishermen and pirates for temporary protection against tempest weather conditions. Fishermen composed the first community permanently founded in the zone. In the interior lands, forestry was the predominant activity for more than a century, with strong operations and trade in precious woods (e.g. mahogany and cedar) and logwood, which was highly value in the international market due to the textile use of the haematoxylin tint [9]. Agriculture was focused on coconuts, which were marketed to cosmetic companies until Lethal Yellowish Disease devastated the coconut tree population in the 1980s and 1990s [10]. 
Some natives were developing farming and moving to the closest cities for better opportunities. Basic services such as electricity and piped water were installed in the middle of the twentieth century. One of the main exploited products in the last century was shrimp, caught by the ton and shipped to United States and other countries. The fishery operated from the 1940s to the 1980s, until the depletion of the resource and the providential discovery of oil deposits near the shore of Campeche state. Since then, the economy of the region, and perhaps of the country, has been based on oil, with the accompanying social and environmental concerns. The establishment of powerful foreign oil companies triggered an active dynamic of people moving from small towns to Ciudad del Carmen. However, despite the strong socioeconomic pressure on rural populations to work in the oil industry, some traditional activities persist and tourism can be developed as a principal livelihood.

\subsection{Present conditions, described using tourism and sustainability indicators}

Despite the gradual changeover of the region from traditional activities to tourism over the past ten years, services and infrastructure to cover guest needs are still basic. According to the answers obtained in the visitor questionnaires, most visitors travel from neighbour states (84\%), some travel from other regions of Mexico (15\%), and only $1 \%$ travel from other countries. In general, visitors required more information about the activities and places to visit around the towns and additional and better services (e.g. transport, banks, payment facilities and public security). Despite those requests, people visiting the villages and surrounding natural environments considered it a positive experience, table 2 .

Table 2: Percentage of answers to key social, economic and environmental aspects. Completely disagree (CD), disagree (D), indecisive (I), agree (A) and completely agree (CA). Sample $\mathrm{N}=231$.

\begin{tabular}{lccccc}
\hline Question & CD & D & I & A & CA \\
Was your visit a positive experience? & 0.0 & 0.0 & 11.3 & 8.6 & 80.1 \\
Did you take part in a variety of activities? & 4.9 & 8.0 & 13.7 & 15.8 & 57.6 \\
Did you feel comfortable and safe? & 0.0 & 3.4 & 7.9 & 8.2 & 80.5 \\
& & & & & \\
Were the services good - price/quality? & 5.0 & 10.1 & 41.5 & 26.1 & 17.3 \\
Was the accommodation good - p/q? & 11.1 & 15.0 & 45.0 & 17.7 & 11.2 \\
Was the food good - price/quality? & 10.0 & 7.7 & 34.2 & 12.9 & 35.2 \\
& & & & & \\
Did you perceive the locations to be clean? & 21.6 & 1.7 & 29.8 & 8.6 & 38.1 \\
Did you consider ecosystems preserved? & 0.0 & 1.7 & 9.5 & 31.6 & 57.1 \\
Were the nature places varied? & 0.0 & 0.0 & 5.6 & 9.5 & 84.8 \\
\hline
\end{tabular}


From the economic perspective, approximately half of the visitors found the quality and price of food, hotels and services reasonable; the other half was divided between tourists who found the services relatively costly or inexpensive, table 2 . There is no appropriate supervision of the prices for restaurants, hotels and tours. Almost $50 \%$ of the tourists were not sure if they are paying acceptable prices and between 5 and $15 \%$ opined that price does not reflect quality, table 2 . Among the natural attractions of the NPA, $48 \%$ of the visitors preferred the fauna observation tours, $34 \%$ preferred the sun and beach, and $18 \%$ preferred the boat excursions through the estuarine ecosystems. Visitors responded that the cleanness and preservation of the natural environments was excellent (12\%), good (49\%), regular $(27 \%)$ or bad $(13 \%)$. Most of the tourists $(95 \%)$ demanded further information about sanctuaries and remote, pristine places. Only a small number of visitors received information about the biodiversity at the NPA and the condition of the natural resources; however, they found the area stimulating and varied, table 2.

Sustainability indicators demonstrated that among the residents interviewed, most of them were employed (90\%), mainly in basic services such as transport, local commerce and construction (39\%). Approximately 30\% were dedicated to fishing, agriculture and forestry. Results indicated that sustainability indicators associated with the poverty theme were determinants, explaining the values observed in other indicators and the overall picture of the region. Half of the residents of the surveyed town live in poverty, according to the Monthly National Minimum Salary, which is about US\$ 150.00 , with men earning almost double what women. On the other hand, $90 \%$ of the local population had access to basic housing services (electricity, piped water, telephone lines and public lighting). One of the indicators proposed by the UN Commission for Sustainable Development in 2007 to reflect access to information was the proportion of the population with Internet access [11]; only $15 \%$ of the surveyed population has that service, fig. 2.

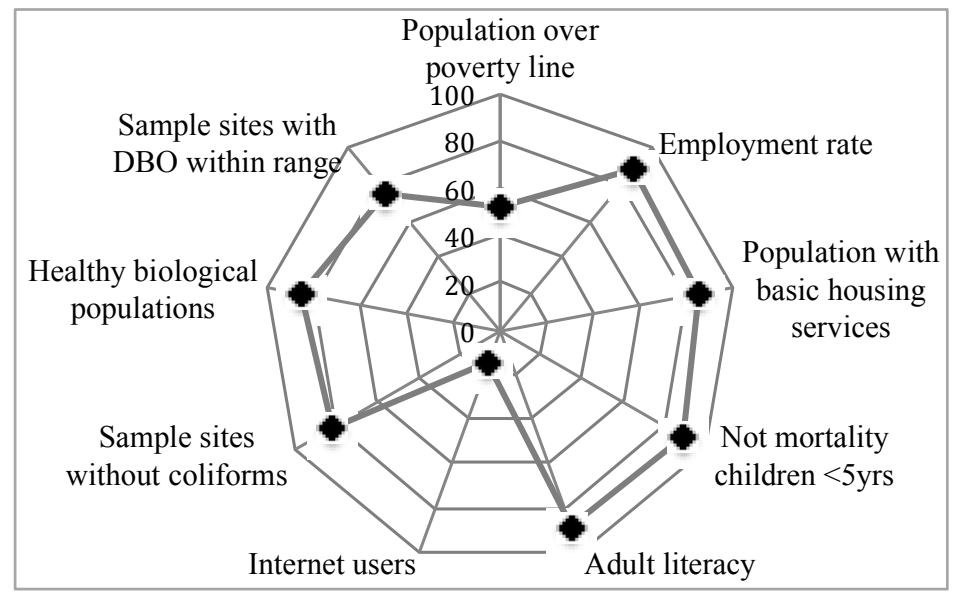

Figure 2: Sustainability indicators. 
Indicators related to health revealed that mortality of children under 5 years is at an acceptable level, according to the UN Millennium Development Goals; however, the percentage of people with access to primary health care is still poor $(68 \%)$. Education indicators showed evidence of limited progress toward sustainability. Enrolment in primary school was at $86 \%$, whereas the international goal of the sustainable agenda is $100 \%$. Adult literacy for the two communities studied was $88 \%$ when the expected percentage is $95 \%$, fig. 2 .

Approximately $80 \%$ of the residents opined that tourism represents long-term progress for the community through the creation of new and better-paying jobs; the remaining percentage affirmed that it is not a good idea to change traditional activities to ecotourism. Although $80 \%$ opined that tourism would produce better living conditions, $30 \%$ was concerned about the possibility of a rise in crime and the loss of moral, religious and behavioural customs, fig. 3. An important percentage believes that touristy activities imply an increase of local prices, but stimulates the economy, fig. 3. A general perception among locals is the necessity for greater abilities to offer educational eco-tours and a consistent investment in tourist infrastructure and services by government and private companies.

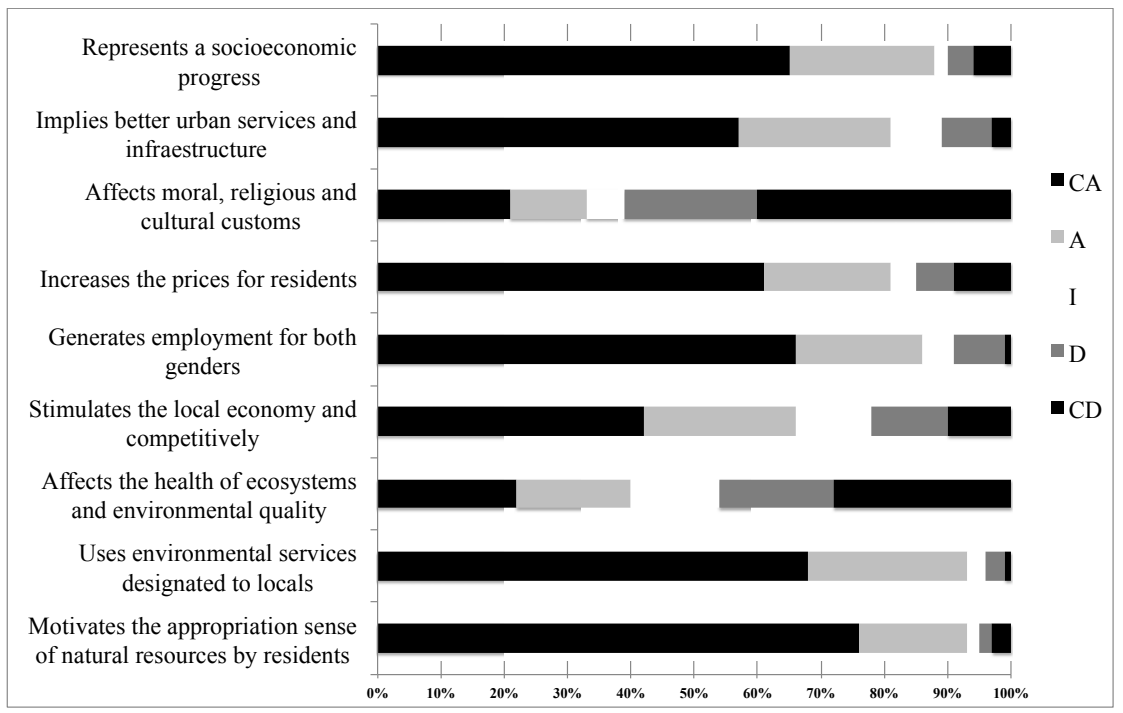

Figure 3: Percentage of answers by residents to key social, economic and environmental aspects. Completely agree (CA), agree (A), indecisive (I), disagree (D), completely disagree (CD). Sample $N=500$.

The results of this research demonstrate a lack of information, particularly on environmental subjects concerning the use of natural resources, the carrying capacity of ecosystems and the potential effects of pollution from urban and tourist activities on regional habitats and species. Despite an evident motivation of the sense of appropriation of natural capital by the residents, there is an evident lack of knowledge about probable environmental threats and the means to avoid or 
mitigate the human effects. In Mexico, the Secretariat of Environment and Natural Resources establishes environmental protection standards, especially for NPAs; the problem lies in the accomplishment of those standards. Similarly, the Tourism Secretariat establishes rules about the permitted activities at tourist destinations, where the protection of cultural and environmental heritage is concerned, the problem is that the standards are not properly implemented, clearly communicated, supervised or respected. These idiosyncrasies emphasize the sustainability risks for local communities and environments, because there is no guarantee of a successful tourism planning process and implementation.

\subsection{Prospective ecotourism activities}

The data, information and indicators gathered for this research allow us to suggest some particular ecotourism activities consistent with the principles of sustainable development. The proposal design was elaborated according to the present management plan of the NPA, which mentions basic guidelines: i) ecotourism activities must have a low environmental impact and should be complemented by environmental instruction and represent a direct benefit to local communities; ii) activities must use only the existing transit paths and navigation routes; iii) visitors cannot collect any minimal natural element; and iv) the tourism guide or service provider will be responsible for any damage caused to the habitat.

The proposed route combines visits to the main natural attractions and local landmarks with recreational low-impact activities. The excursion starts with kayaking in the lagoon to observe dolphins and sea birds traversing the narrow, stretched estuarine channels bordered by mangrove and rainforest vegetation. Next, from the main berth of Isla Aguada, a boat initiates a course from the interior of the lagoon ecosystem toward Sabancuy town, visiting the Ti-Xel ex-hacienda for a walk and instruction in cultural topics and the traditional uses of natural resources. The next stop will be Sabancuy town to visit the local seafood and handcraft market. The course continues by the seaside, finishing at sunset on the beach of Isla Aguada for the sea turtle hatchling release. Finally, night activities will include a visit to the lighthouse, the parks downtown and the main buildings, led by a motorbike guide. The route proposes combines the visit to the main natural attractions, landmarks on towns and recreational low impact activities.

\section{Conclusions}

Results demonstrated that the historic use of natural resources has been clearly unsustainable. Currently, despite the relative well-conserved environmental ecosystems and cultural places there is not guarantee to maintain the benefits for a long time. Socioeconomic indicators show that poverty and marginalization result in a low quality of life, inaccessible basic services and average socioeconomic condition (education, health, employment and salary) for local people.

Tourism is perceived by visitors and residents as a good option to improve the regional economy offering a competitive service. We believe that ecotourism 
activities have the potential to develop as the predominant activity at the region with a proper planning process based on sustainable prospective and scientific support. New information is needed as part of a participative scheme and the application of accurate indicators in the government regulations, monitoring and investments.

\section{References}

[1] United Nations World Tourism Organization (UNWTO). Indicators of Sustainability for Tourism Destinations - a Guidebook. Madrid, Spain, p. 545, 2005.

[2] Drum, A. \& Moore, A., Ecotourism Development - A Manual for Conservation Planners and Managers (Volume I) An Introduction to Ecotourism Planning. The Nature Conservancy, 2004.

[3] United Nation List of Protected Areas (IUCN), United Nations, 2003.

[4] Bringas N. \& Ojeda L., El ecoturismo ¿una nueva modalidad del turismo de masas? Economía, sociedad y territorio. 2(7), p. 403, 2000.

[5] UNEP, 2002.

[6] Sansbelló, R.M.F., Flores, J.C.M. \& Puerta, D.L., Ecoturismo en el trapecio amazónico colombiano: ¿Una alternativa de desarrollo? España: Universitat de Girona, pp. 187-196, 2002.

[7] Sundström, S., El ecoturismo como instrumento para desarrollo sostenible: Un estudio comparativo de campo entre Suecia y Ecuador. Suecia: Karlstads Universitet: Institutionen för Kultur och kommunikation, 2003.

[8] Moreno-Casasola, P., A case study of Conservation and Management of Tropical Sand Dune Systems: La Mancha-El llano. Springer Home Journals, Academic Books \& Online Media, 2004.

[9] Vadillo C., La significación de los bosques y el agua. El territorio de la Laguna de Términos 1675-1997. México: Universidad Autónoma del Carmen, Colección Documentos e Investigación. p. 146, 2003.

[10] Álvarez L., Diccionario Enciclopédico Ilustrado de la Laguna de Términos. México: Universidad Autónoma del Carmen y Gobierno del Estado de Campeche, Tomo IV. pp. 935-940, 2003.

[11] United Nations. Indicators of Sustainable Development: Guidelines and Methodologies, Third Edition, United Nations, New York, 2007. 